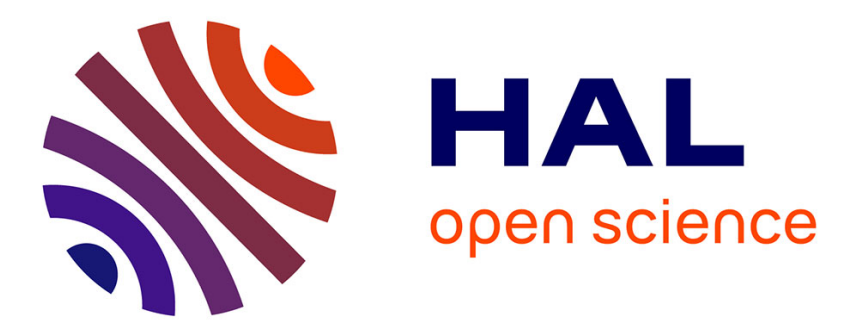

\title{
Spectral characteristics of atmospheric pressure and electric field variations under severe weather conditions at high latitudes
}

\author{
E. A. Kasatkina, O. I. Shumilov, Y. A. Vinogradov, A. N. Vasilyev
}

\section{- To cite this version:}

E. A. Kasatkina, O. I. Shumilov, Y. A. Vinogradov, A. N. Vasilyev. Spectral characteristics of atmospheric pressure and electric field variations under severe weather conditions at high latitudes. Atmospheric Chemistry and Physics Discussions, 2006, 6 (4), pp.6613-6626. hal-00301984

\section{HAL Id: hal-00301984 \\ https://hal.science/hal-00301984}

Submitted on 17 Jul 2006

HAL is a multi-disciplinary open access archive for the deposit and dissemination of scientific research documents, whether they are published or not. The documents may come from teaching and research institutions in France or abroad, or from public or private research centers.
L'archive ouverte pluridisciplinaire HAL, est destinée au dépôt et à la diffusion de documents scientifiques de niveau recherche, publiés ou non, émanant des établissements d'enseignement et de recherche français ou étrangers, des laboratoires publics ou privés. 


\section{Spectral characteristics of atmospheric pressure and electric field variations under severe weather conditions at high latitudes}

E. A. Kasatkina ${ }^{1}$, O. I. Shumilov ${ }^{1}$, Y. A. Vinogradov ${ }^{2}$, and A. N. Vasilyev ${ }^{3}$

${ }^{1}$ Institute of North Industrial Ecology Problems, Kola Science Centre RAS, Fersmana str. 14, 184209 Apatity, Russia

${ }^{2}$ Kola Regional Seismological Center (KRSC) of Geophysical Survey of RAS, 184209 Apatity, Russia

${ }^{3}$ Polar Geophysical Institute, Kola Science Centre RAS, 184209 Apatity, Russia

Received: 8 May 2006 - Accepted: 14 June 2006 - Published: 17 July 2006

Correspondence to: E. A. Kasatkina (oleg@aprec.ru)
ACPD

6, 6613-6626, 2006

Spectral

characteristics of atmospheric

parameters

E. A. Kasatkina et al.

Title Page

Abstract

Introduction

Conclusions

References

Tables

Figures

14

$\rightarrow$

4

Back

Close

Printer-friendly Version

Interactive Discussion 


\section{Abstract}

The time-dependent relationships between atmospheric parameters (electric field, positive and negative conductivity, variations of atmospheric pressure) and different meteorological phenomena (rain, fogs, snowstorms, thunderstorms) were investigated

5 through spectral analysis. These parameters were measured with help of a highlatitude computer-aided complex installed at Apatity $(66.5 \mathrm{~N}, 33.4 \mathrm{E})$. The complex consists of three spaced microbarographs for measurements of atmospheric pressure variations in the range of periods from $1 \mathrm{~s}$ to $40 \mathrm{~min}$, an instrument measuring the vertical component of the electric field, and instrument used for measurements of air conductivity and surface ozone. A computer-aided data-gathering system makes it possible to obtain information in the frequency range between 1 and $0.0001 \mathrm{~Hz}$. The time-dependent frequency analysis showed that the spectral characteristics of both electric field and atmospheric pressure variations changed synchronously during severe weather conditions.

\section{Introduction}

As it is known short period variations of atmospheric electric field $E_{z}$ are connected to various meteorological phenomena of local character (clouds, fogs, industrial aerosols, thunderstorm activity) (Chalmers, 1967; Bhartendu, 1971; Holzworth, 1981; Anisimov et al., 1994; Rycroft, 1994; Guo et al., 1996). At the same time, the appearance of atmospheric electric field and pressure pulsations can also be connected to magnetospheric disturbances at high latitudes (Holzworth, 1981; Ivanov and Semenov, 1984; Goldberg et al., 1990; Nikiforova et al., 2003). In this connection the development of new integrated methods of observation for revealing meteorological and magnetospheric sources in polar atmosphere seem to be very promising.

25 To this end, in Kola Science Center of RAS (Apatity, $66.5 \mathrm{~N}, 33.4 \mathrm{E}$ ) it was installed High-latitude computer-aided measuring complex. The complex consists of three

\section{Spectral characteristics of atmospheric parameters}

E. A. Kasatkina et al.

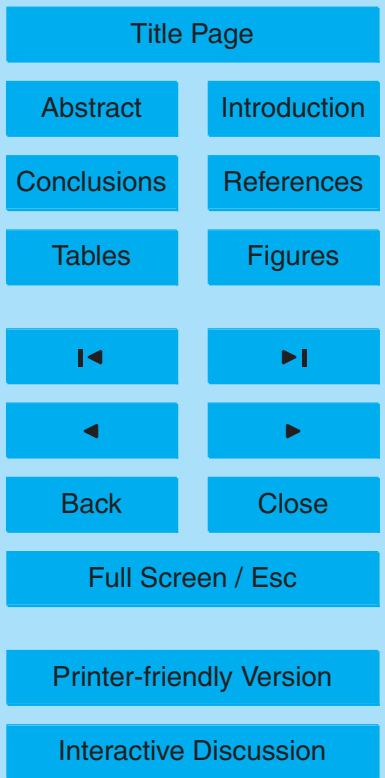


spaced (about $300 \mathrm{~m}$ ) microbarographs for measurements of atmospheric pressure variations in the frequency range from 0.0001 to $1 \mathrm{~Hz}$, an instrument measuring the vertical component of the electric field, and instrument used for measurements of air conductivity and surface ozone, telemetry, and system for data gathering (Shumilov et 5 al., 2002). The complex is located not far from Khibini mountains that create favourable conditions for observation of non-stationary mountain waves (Shumilov et al., 2002).

In the present paper the time-dependent relationships between atmospheric parameters (electric field, positive and negative conductivity, variations of atmospheric pressure) and different meteorological phenomena (rain, fogs, snowstorms, thunderstorms) were investigated through spectral analysis.

\section{Instrument and data description}

Measurements of low-frequency infrasound pressure oscillations in frequency range $(0.0001-1 \mathrm{~Hz})$ were carried out by means of liquid microbarographs developed by the Oboukhov Institute of Atmospheric Physics RAS (Bovsheverov et al., 1979). For deter15 mination of infrasound source spatial characteristics (azimuth, arrival time) three onetype sensors have been installed at angle tops of approximately equilateral triangle with nearly equal sides $(\sim 300 \mathrm{~m})$. In the device three wide-band filters with frequency bands $1 \mathrm{~s}-40 \mathrm{~min}, 1-40 \mathrm{~min}$ and $5-40 \mathrm{~min}$ were used. The information was transmitted with help of telemetry system consisting of two independent channels.

20 The complex contains also the vertical electric field measuring device "Pole-2" and conductivity measuring device "Electroprovodnost -2 ". The positive and negative atmospheric electrical conductivities $\left(\lambda_{-}\right.$and $\left.\lambda_{+}\right)$were measured by aspirating air through two capacitor electrodes. The main idea of the method is based on the measurement of atmospheric ion current. These ions get into one of the two cylindrical capacitor electrodes. Depending on its sign. A pump is used for creation of ion stream into the cylindrical capacitor. The device permits to measure the air electrical conductivity with an absolute accuracy up to $\sim 10^{-16} \Omega^{-1} \mathrm{~m}^{-1}$. Speed of air stream pumping is about

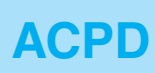

$6,6613-6626,2006$

\section{Spectral characteristics of atmospheric parameters}

E. A. Kasatkina et al.

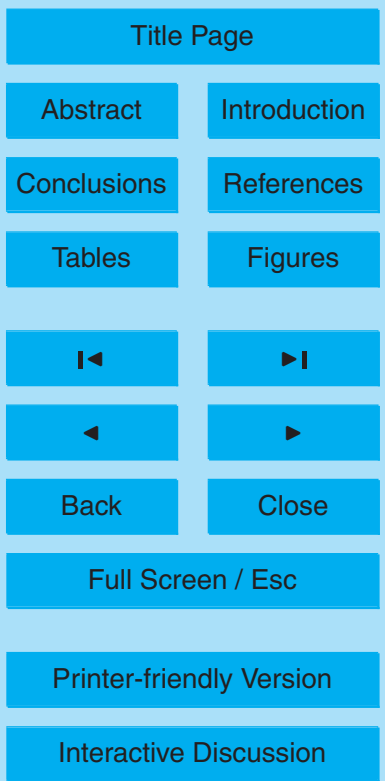


$20 \mathrm{l} / \mathrm{min}$, and time constant is $\sim 100 \mathrm{~s}$. The main point of the method used in the measuring device "Pole-2" consists of transformation of the electrostatic induction constant flux into the alternating one at the surface of the receiving element. On the load that is connected with the receiving element an alternating current flow. Voltage drop on 5 the load is proportional to $E_{z}$ strength. The device has got two limits of electric field strength measurements $- \pm 5000 \mathrm{~V} / \mathrm{m}$ and $\pm 500 \mathrm{~V} / \mathrm{m}$. The measurement accuracy is $20 \%$.

In the data gathering system seven channels were used. The first three ones gained information from microbarograph sensors with a polling frequency of five times per 10 second. The next four channels transformed signals with a polling frequency of ten times per second from both the electric field and conductivity sensors. As a result a diurnal data file was formed and then transferred into the data storage.

\section{Results and discussion}

\subsection{Rain}

15 An example of $E_{z}$ and electrical conductivity variations during a rain on 28 June 2002 is given in Fig. 1. The rain period was observed between 14:00 and 16:00 UT. After some break the rain was again detected near 18:00 UT, when $E_{z}$ value decreased up to background value. In the case the rain seemed to cause charge sink that was formed in the lower part of thunderstorm cloud. Figure 2 shows a time-dependent (dynamical) spectrum of $E_{z}$ variations for the event considered. It was computed by the windowed discrete-time Fourier transform of a signal using a sliding window (Rabiner and Schafer, 1978). It is seen that $E_{z}$ was accompanied by the appearance of oscillations with periods $T>1 \mathrm{~min}$. After the rain start at $\sim 18: 00$ UT $E_{z}$ variations disappeared.

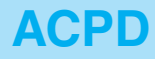

6, 6613-6626, 2006

\section{Spectral characteristics of atmospheric parameters}

E. A. Kasatkina et al.

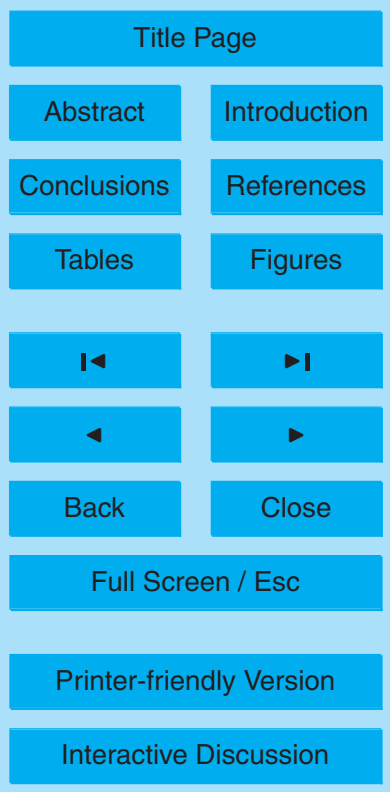




\subsection{Thunderstorm}

An event of rather strong thunderstorm accompanied lightning has been detected on 29 June 2002. Note that thunderstorms with lightnings are very seldom behind the polar circle (not more than two-three per year). This day the strong thunderstorm

5 with lightnings started between 13:10-13:20 UT. At the moment considerable variations of $E_{z}$ with amplitudes $\sim 10 \mathrm{kV} / \mathrm{m}$ and sign changes were detected (see Fig. $3 \mathrm{~b}$ ). Figure 4 demonstrates a dynamical spectrum of $E_{z}$ and atmospheric pressure variations during thunderstorm. It is clearly seen that $E_{z}$ with periods $T>1$ min coincide with thunderstorm activity beginning (see Fig. 4a). Strong jumps in the pressure variations were measured practically simultaneously with $E_{z}$ changes after thunderstorm start (Figs. 3a, 4b). A lot of papers are devoted to infrasound generation by lightning discharges (Balashandran, 1979; Grigorjev and Dokuchaev, 1981).

It should be pointed out that high-frequency component of atmospheric pressure variations ( $2 \mathrm{~min}<T<6 \mathrm{~min})$ temporally coinciding with the start and development of thunderstorm activity appeared at the background of already existing slow variations of pressure with $\mathrm{T}>6 \mathrm{~min}$, that are probably related to the connection and propagation of mountain lee waves (Shumilov et al., 2002). The result obtained coincides with data given in works (Balashandran, 1979; Grigorjev and Dokuchaev, 1981) where the possibility of infrasound and internal gravity wave generation by lightning discharge is considered.

\subsection{Fog}

Figure 5 shows the measured atmospheric pressure $P$, vertical electric field $E_{z}$ and electrical conductivity variations during a fog on 3 December 2001. On the day the air temperature was stable $\left(-5^{\circ} \mathrm{C}\right)$, any precipitation was absent, and a weak wind flew. Approximately at 06:00 UT a strong fog started to develop (visibility was less than $50 \mathrm{~m}$ at the moment). The fog then existed up to 22:00 UT. Since the time of the fog formation (06:00 UT) a slow increase in $E_{z}$ took place and lasted up to midday hours

\section{Spectral characteristics of atmospheric parameters}

E. A. Kasatkina et al.

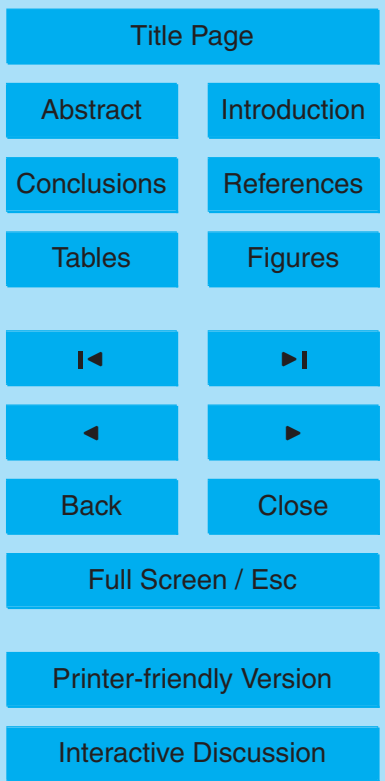


(see Fig. 5b). Maximal values of $E_{z}$ reached $1 \mathrm{kV} / \mathrm{m}$ that exceeded nearly by one order the background values and agreed with experimental data and theoretical estimates (Bott et al., 1990). In the evening, when the fog scattered, electric field decreased, but still exceeded the background value by two-three times. Air electrical conductivity 5 decreased at the time (see Fig. 5c). It was noted on conductivity drop during a fog by Chalmers (1967). The increase of $E_{z}$ and decrease of electrical conductivity during the fog formation seemed to be connected to the aerosol condensation growth in the air and attachment of the light ions to the aerosol particles.

Together with start of considerable changes in electric field some changes in at10 mospheric pressure were also detected (decrease of the variation amplitude and appearance of high-frequency component (see Fig. 5a). According to Figs. 6a, b, the dynamical spectra of electric field (a) and atmospheric pressure (b) demonstrate a noise burst in a wide-frequency band at 08:00 UT. It is seen from Fig. 6a that this effect is not so noticeably expressed in $E_{z}$ spectrum which consists of equally spaced

15 frequency bands with a width of $\sim 0.005 \mathrm{~Hz}$. The noise burst disappeared after the fog vanished. Probably the pressure fluctuations were related to formation of stretched "aeroelectrical" structures filled in a turbulent gas in fog conditions (Anisimov et al., 1994).

\section{Conclusions}

20 The time-dependent spectral analysis of atmospheric pressure and electric field variations under severe weather conditions (rain, fog, thunderstorm) showed that the frequency characteristics of both parameters changed practically synchronously.

The obtained results note onto the validity of investigation of atmospheric parameter variations at high latitudes with help of the integrated methods measuring several 25 quasi-independent atmospheric parameters simultaneously. This approach seems to permit us to create not contradicting scheme of physical processes in atmosphere.

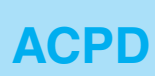

$6,6613-6626,2006$

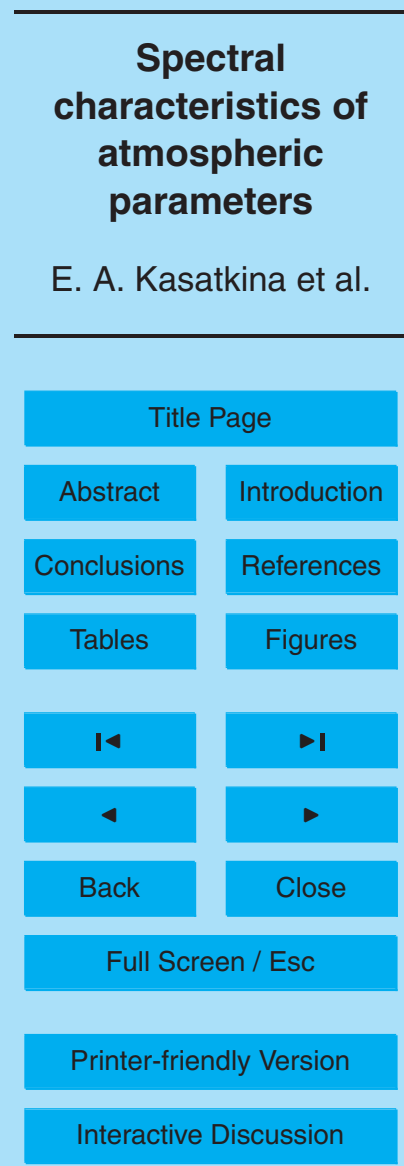


Acknowledgements. This research was supported by the Russian Foundation for Basic Research (grant N 05-04-97528) and by the Regional Scientific Program of Murmansk region.

\section{References}

Anisimov, S. V., Bakastov, S. S., and Mareev, E. A.: Spatiotemporal structures of electric field and space charge in the surface atmospheric layer, J. Geophys. Res., 99, 10603-10610, 1994.

Balashandran, N. K.: Infrasonic signals from thunder, J. Geophys. Res., 84, 1135-1145, 1979.

Bhartendu, S.: Relation of the atmospheric potential gradient with meteorological elements: Cross power spectral analysis, Pure Appl. Geophys., 88, 210-227, 1971.

Bott, A., Sievers, U., and Zdunkovski, W.: A radiation fog model with detailed treatment of the interaction between radiate transfer and fog microphysics, J. Atmos. Sci., 47, 2153-2166, 1990.

Bovsheverov, B. V., Grachev, A. I., Lomadze, C. O., and Matveev, A. K.: Liquid microbqrograph, Izv. AN SSSR. (in Russian), Phys. Atmos. Ocean, 15, 1215-1218, 1979.

15 Chalmers, J. A.: Atmospheric electricity, Tarrytown, NY, Pergamon, 195 pp., 1967.

Goldberg, R. A., Croskey, C. L., Hale, L. C., Mitchell, J. D., and Barcus, J. R.: Electrodynamic response of the middle atmosphere to auroral pulsations, J. Atmos. Terr. Phys., 52, 10671084, 1990.

Grigorjev, G. I. and Dokuchaev, V. P.: Infrasound and internal gravity waves under thunderstorm discharges in atmosphere, Izv. AN SSSR. (in Russian), Phys. Atmos. Ocean, 17, 690-697, 1981.

Guo, Y., Barthakur, N. N., and Bhartendu, S.: The spectral relationships between atmospheric electrical conductivity and air pollution in urban conditions, J. Geophys. Res., 101, 69716977, 1996.

25 Holzworth, R. H.: High latitude stratospheric electrical measurements in fair and foul weather under various solar conditions, J. Atmos. Terr. Phys., 43, 1115-1125, 1981.

Ivanov, K. G. and Semenov, I. H.: Appearance of low-frequency pressure fluctuations at the earth surface during magnetospheric substorms, Geomagnetism and Aeronomy (in Russian), 24, 857-858, 1984.

Nikiforova, N. N., Kleimenova, N. G., Kozyreva, O. V., Kubitski, M., and Michnowski, S.: Influ-

6, 6613-6626, 2006

\section{Spectral characteristics of atmospheric parameters}

E. A. Kasatkina et al.

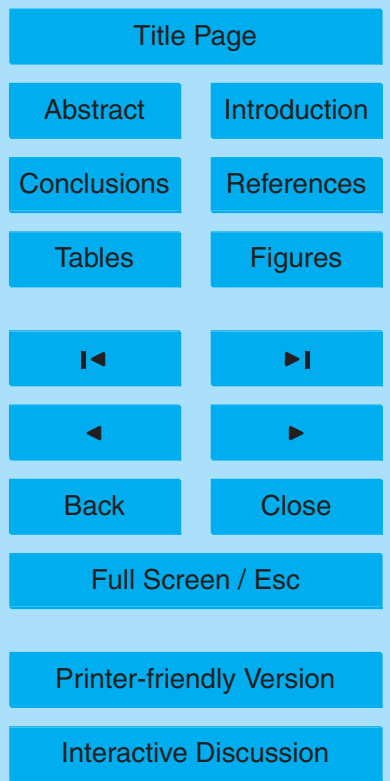


ence of auroral-latitude precipitations of energetic electrons on variations in the atmospheric electric field at polar latitudes (Spitsbergen Archipelago), Geomagnetism and Aeronomy (in Russian and English), 43, 29-36, 2003.

Rabiner, L. R., and Schafer, R. W.: Digital Processing of Speech Signals, Englewood Cliffs, NJ, Prentice Hall, 1978.

Rycroft, M. J.: Some effects in the middle atmosphere due to lightning, J. Atmos. Terr. Phys., 56, 343-348, 1994.

Shumilov, O. I., Kasatkina, E. A., Tereshchenko, E. D., Vasilyev, A. N., and Raspopov, O. M.: Atmospheric pressure variations in the region of lee waves near the Khibini massif, Izv RAN. (in Russian and English), Phys. Atmos. Ocean, 38, 471-475, 2002.

\section{ACPD}

6, 6613-6626, 2006

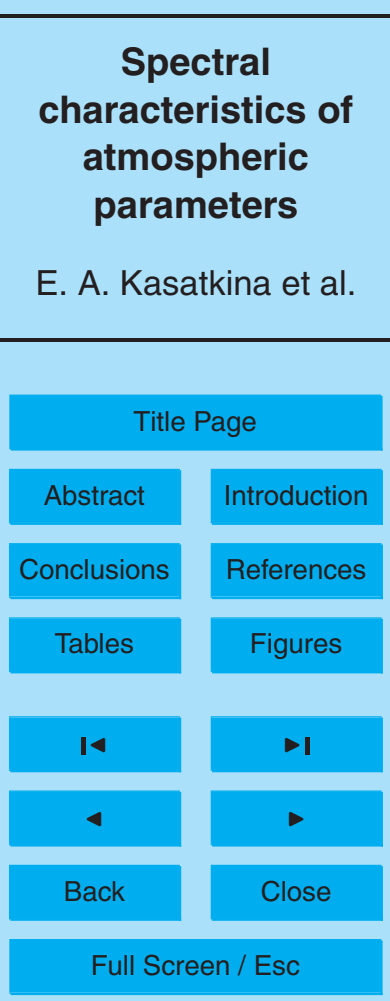

Printer-friendly Version

Interactive Discussion 


\section{ACPD}

\section{6, 6613-6626, 2006}

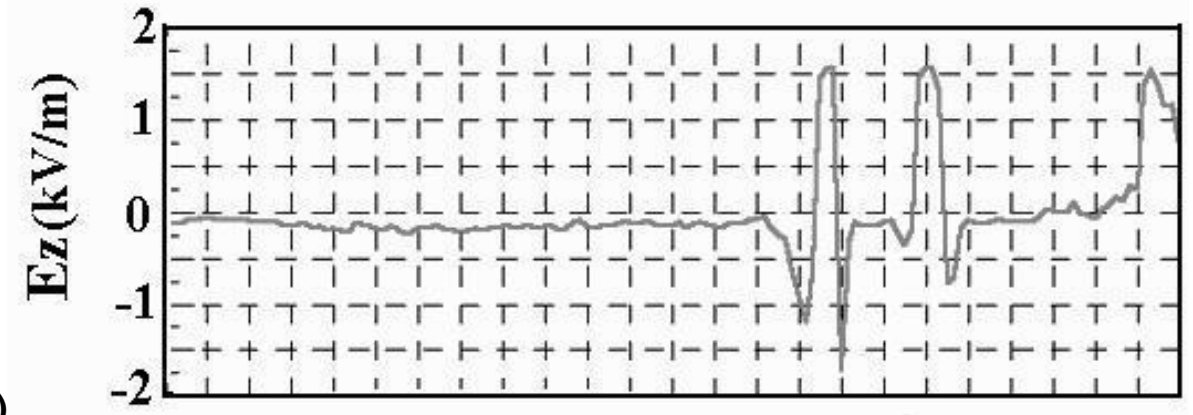

\section{Spectral characteristics of atmospheric parameters}

E. A. Kasatkina et al.

(a)

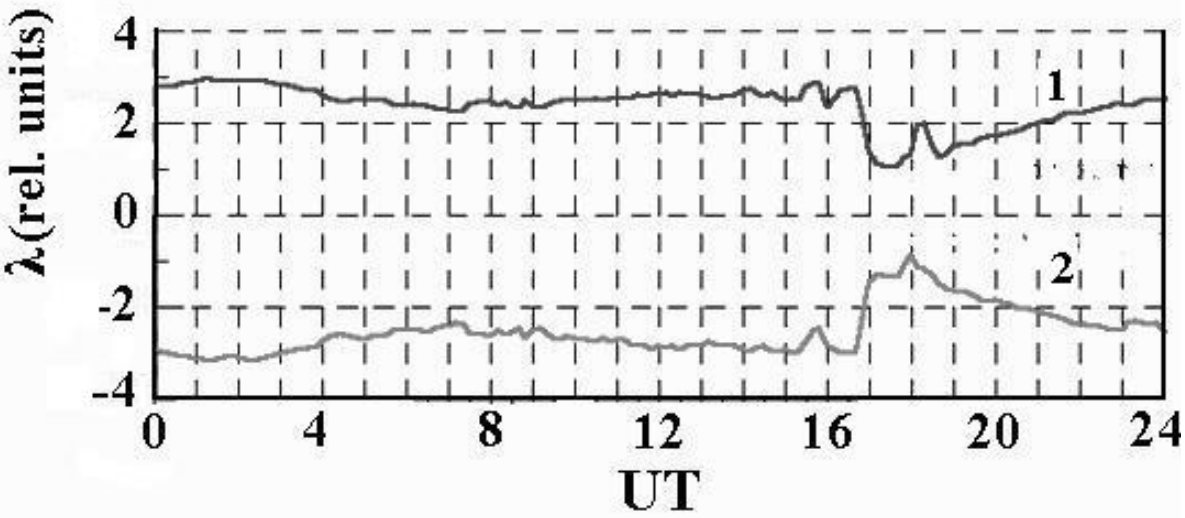

Title Page

Abstract

Introduction

Conclusions

References

Tables

Figures

14

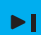

$<$

Back

Close

Full Screen / Esc

Fig. 1. The variations of atmospheric electric parameters (1 min averaged) on 28 June 2002 (rain conditions) at Apatity $(66.5 \mathrm{~N}, 33.4 \mathrm{E})$ : (a) vertical electric field $E_{z}$, (b) positive $\lambda_{+}$(curve 1) and negative $\lambda_{-}$(curve 2 ) electrical conductivity.

Printer-friendly Version

Interactive Discussion 


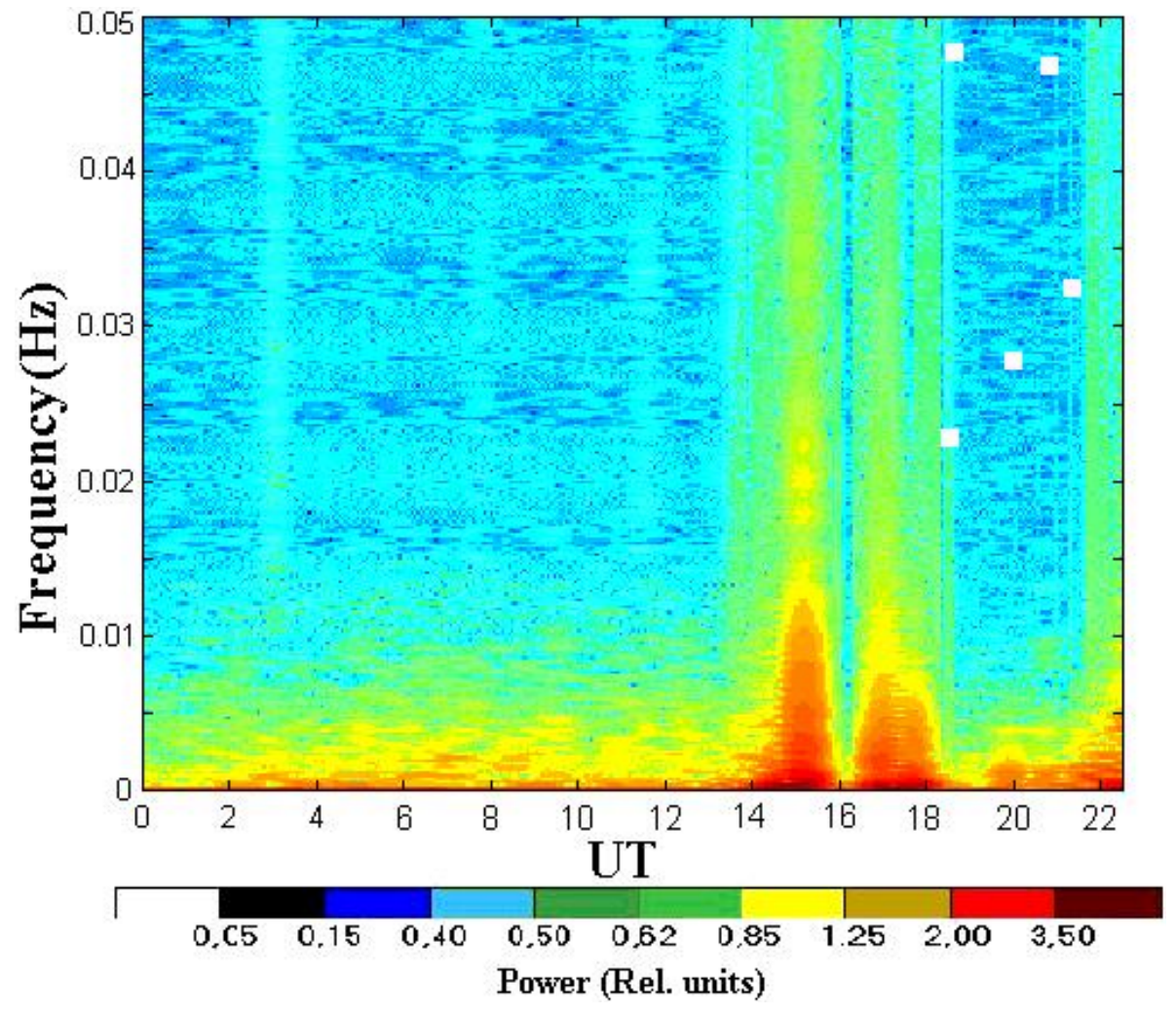

Fig. 2. The dynamical spectrum of $E_{z}$ variations during a rain on 28 June 2002 with sampling frequency of $0.1 \mathrm{~Hz}$.

\section{ACPD}

6, 6613-6626, 2006

\section{Spectral characteristics of atmospheric parameters}

E. A. Kasatkina et al.

Title Page

Abstract

Conclusions

Tables

14

$<$

Back

Full Screen / Esc

Printer-friendly Version

Interactive Discussion 
(a)
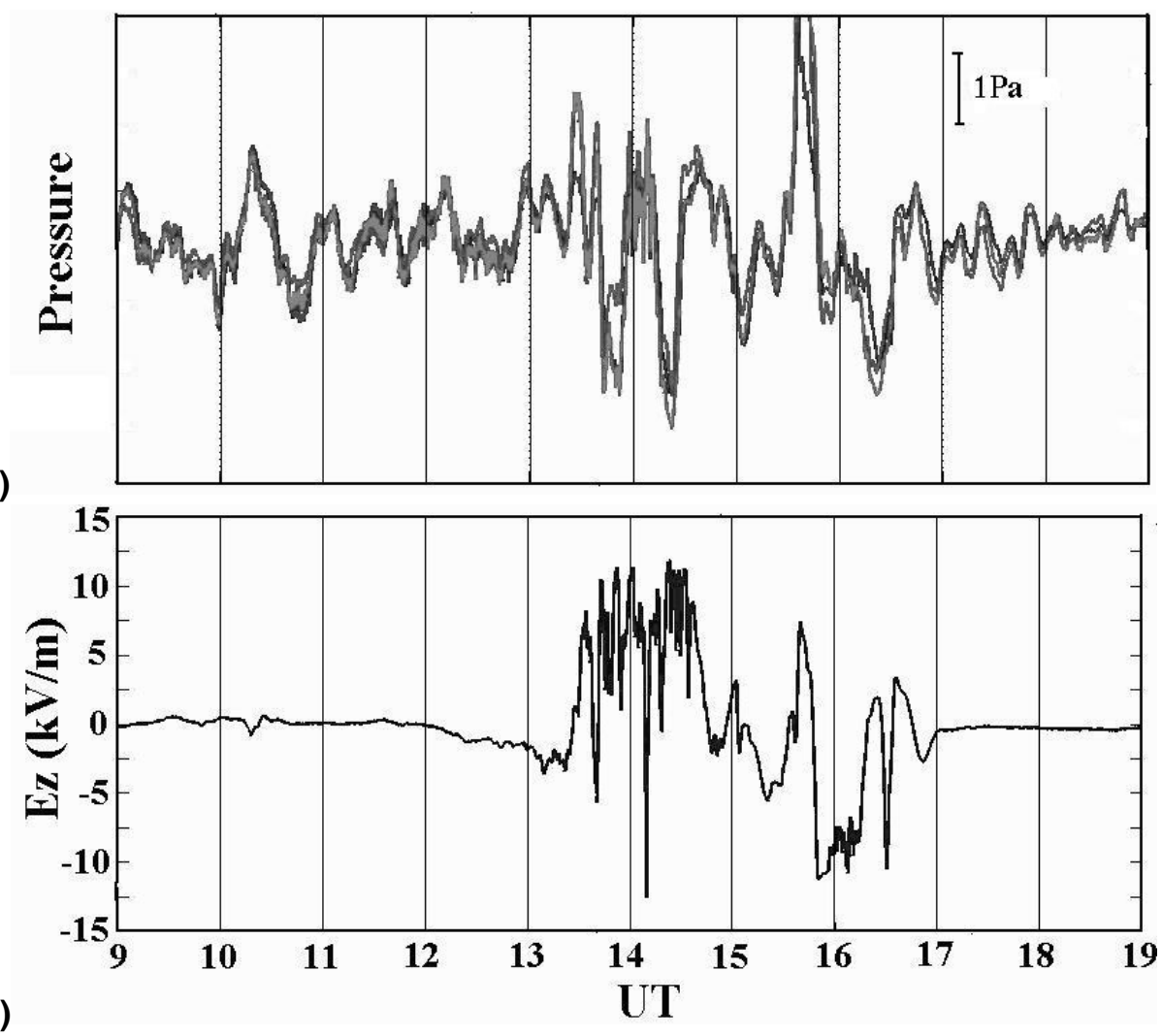

Fig. 3. The variations of atmospheric pressure (a) and vertical electric field $E_{z}$ (b) (10 s averaged) on 29 June 2002 at 09:00 UT to 19:00 UT (thunderstorm conditions).

\section{ACPD}

6, 6613-6626, 2006

\section{Spectral} characteristics of atmospheric parameters

E. A. Kasatkina et al.

Title Page
Abstract

Conclusions

Tables

Tables

14

4

Back 


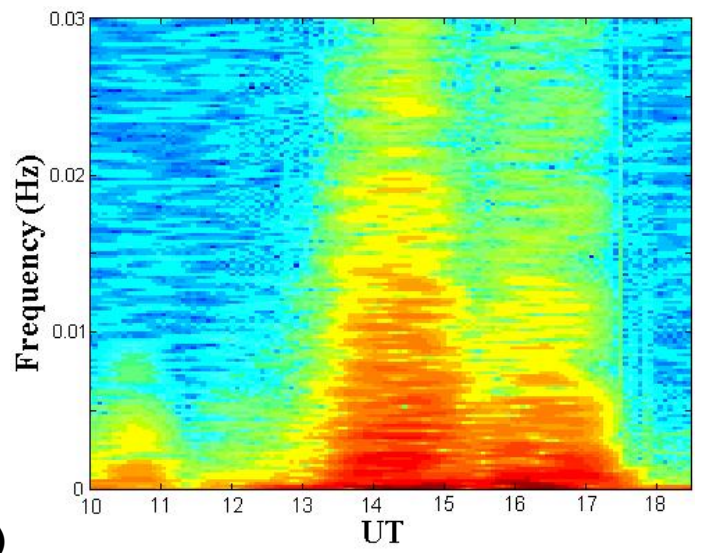

\section{ACPD}

6, 6613-6626, 2006

(a)

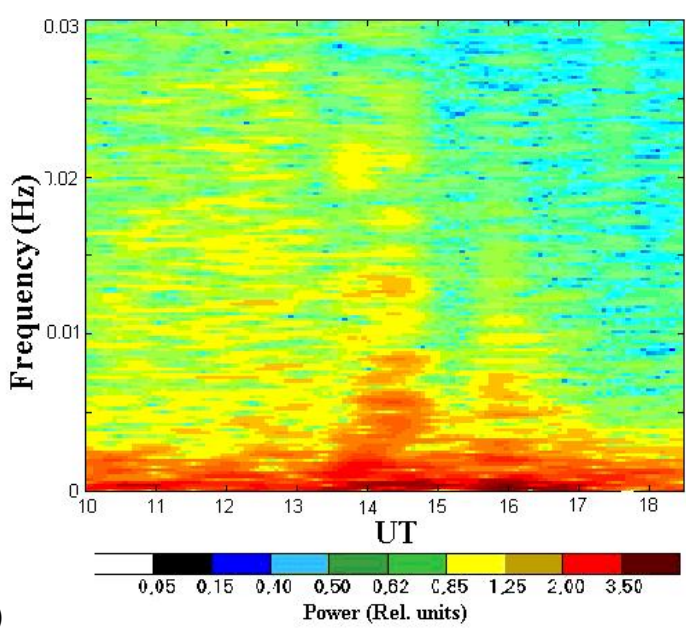

Title Page

Abstract

Introduction

Conclusions

References

Tables

Figures

14

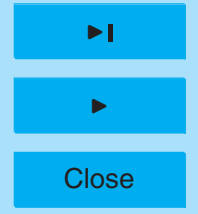

(b)

Fig. 4. Common spectral characteristics in electric field (a) and atmospheric pressure during a thunderstorm on 29 June 2002. Spectrograms were calculated with sampling frequency of 
(a)
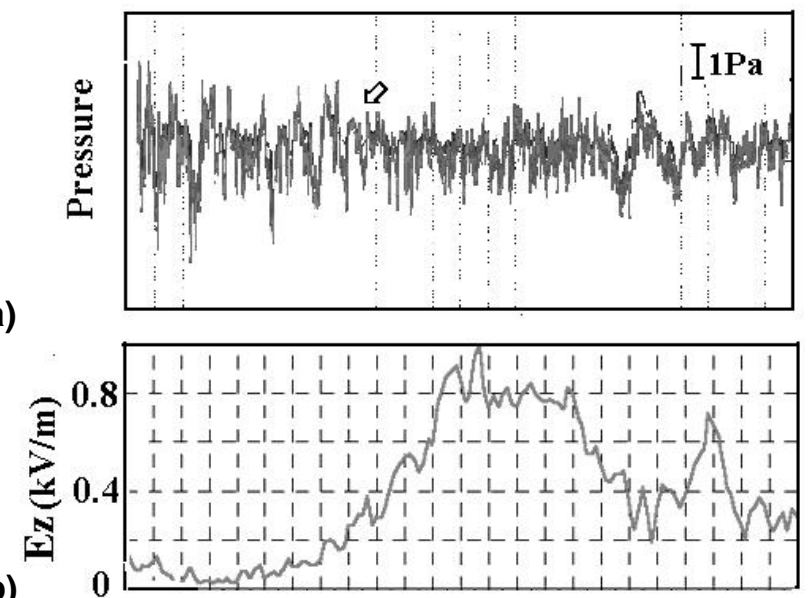

(b)

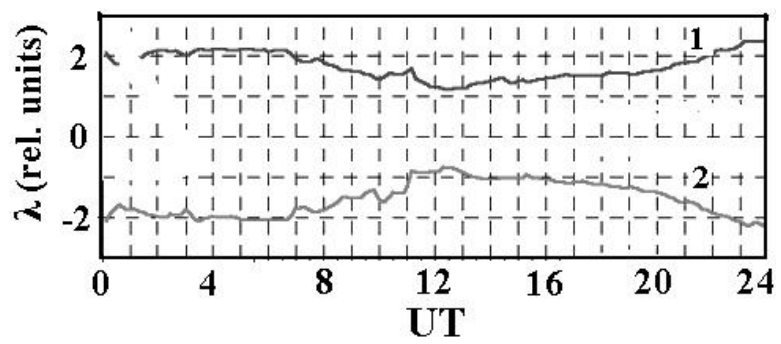

(c)

Fig. 5. The variations of atmospheric parameters (1 min averaged) on 3 December 2001 (fog conditions): (a) atmospheric pressure, (b) vertical electric field $E_{z}$, (c) positive $\lambda_{+}$(curve 1) and negative $\lambda_{-}$(curve 2) electrical conductivity. Arrow shows the appearance of high frequency component in pressure variations.

\section{ACPD}

6, 6613-6626, 2006

\section{Spectral characteristics of atmospheric parameters}

E. A. Kasatkina et al.

\section{Title Page}

Abstract

Introduction

Conclusions

References

Tables

Figures

14

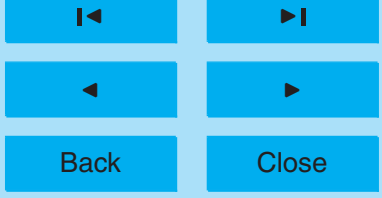

Full Screen / Esc

Printer-friendly Version

Interactive Discussion 
(a)
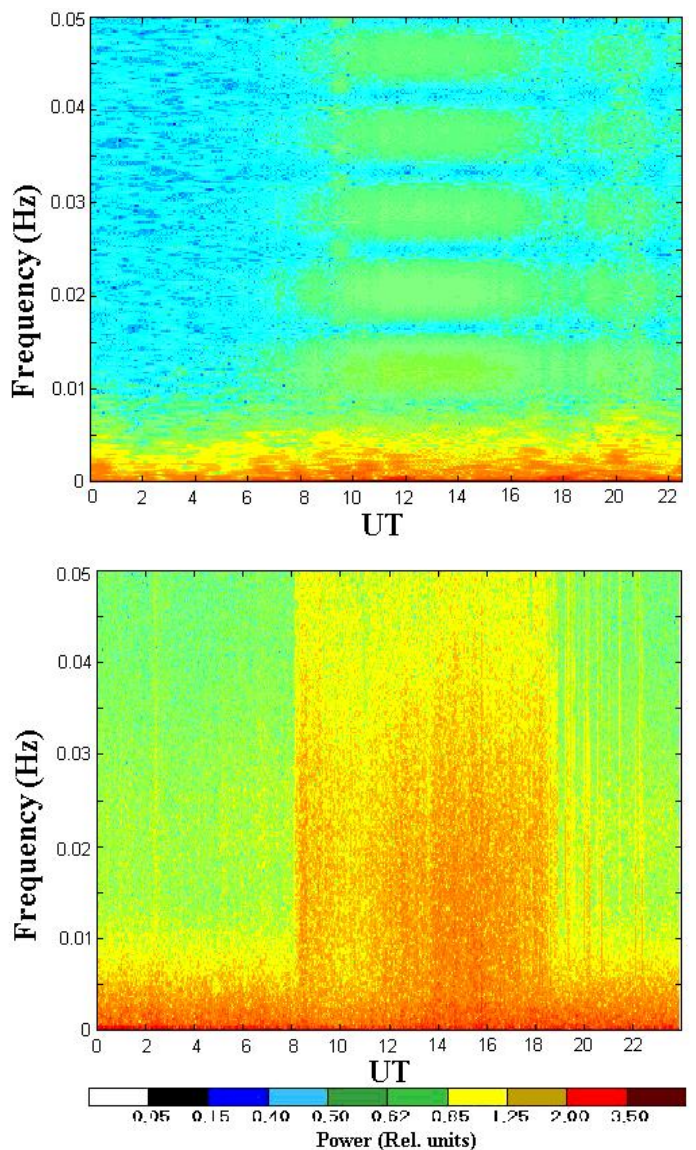

(b)

Fig. 6. The same as in Fig. 4, but during a fog on 3 December 2001.

\section{ACPD}

6, 6613-6626, 2006

\section{Spectral} characteristics of atmospheric parameters

E. A. Kasatkina et al.

Title Page

Abstract Introduction

Conclusions

References

Tables

Figures

14

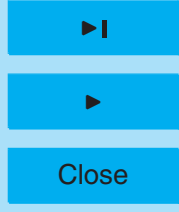

Back

Full Screen / Esc

Printer-friendly Version

Interactive Discussion 